\title{
DISKRESI KEPOLISIAN REPUBLIK INDONESIA RESORT MALANG KOTA \\ DALAM KASUS KECELAKAAN LALU LINTAS
}

\author{
Fachrizal Afandi \\ Fakultas Hukum Universitas Brawijaya Malang \\ Jl. MT. Haryono 169 Malang \\ Email: fachrizalafandi@gmail.com
}

\section{Abstract}

Article 16 (2) and 18 Act. No. 2/2002 of Indonesia Police Officer gives an authority to police officer doing legal actions based on their interpretation. Furthermore Act No 22/2009 of Traffic and Vehicle should can solve impacts problems from traffic accident. This article will focus on the discretional police background and its mechanism in enforcing traffic law.

Key words: discretion, traffic aciident, alternative dispute resolutions

\begin{abstract}
Abstrak
Undang-undang Republik Indonesia Nomor 22 Tahun 2009 tentang Lalu Lintas dan Angkutan Jalan (UU LLAJ) diharapkan dapat menyelesaikan masalah turunan akibat adanya kecelakaan lalu lintas. Pasal 16 ayat (2) dan 18 Undang-undang Nomor 2 tahun 2002 tentang Kepolisian Negara Republik Indonesia memberikan kewenangan penuh kepada pejabat kepolisian untuk bertindak menurut penilaiannya sendiri, dalam kata lain aparat kepolisian memiliki kewenangan untuk melakukan diskresi. Fokus tulisan ini berkaitan dengan faktor yang melatarbelakangi Kepolisian Resort Malang Kota menerapkan diskresi dalam menyelesaikan perkara kecelakaan lalu lintas dan mekanisme penggunaan diskresi yang diterapkan Kepolisian Resort Malang Kota dalam penyelesaian perkara kecelakaan lalu lintas.
\end{abstract}

Kata kunci: diskresi, kecelakaan lalu lintas, mediasi penal

\section{Latar Belakang}

Tujuan utama dari dibentuknya Indonesia sebagai negara hukum adalah untuk memberikan kesejahteraan, keadilan, ketertiban, kepastian serta kemanfaatan bagi masyarakat. Upaya yang dilaksanakan untuk mengejewantahkan tujuan dimaksud tentunya tidak mudah jika penerapan hukum tidak bisa terimplementasi dengan baik. Oleh karenanya negara memiliki kewenangan untuk melakukan upaya paksa agar hukum yang telah disepakati dapat diterapkan dengan baik. 
Negara memliki banyak lembaga penegakan hukum, namun lembaga negara yang dianggap memiliki fungsi penegakan hukum paling luas bagi masyarakat sipil adalah polisi. Kepolisian dianggap sebagai representasi negara dalam melakukan pengawalan pada tiap aturan yang dibuat oleh negara. Pekerjaan kepolisian adalah pekerjaan penegakan hukum in optima forma, seringkali disebut sebagai hukum yang hidup karena pekerjaannya yang langsung berhadapan dengan masyarakat dan dipaksa memiliki kemampuan untuk menafsirkan undangundang tertulis dalam kehidupan nyata.

Kepolisian sebagai institusi terdepan dalam upaya penegakan hukum memiliki kewenangan antara lain serangkaian penyelidikan, penggeledahan, penangkapan, pemeriksaan dan melimpahkan perkara ke kejaksaan untuk dapat disidangkan di pengadilan. Dengan rangkaian urutan kegiatan tersebut nampak bahwa polisi adalah institusi yang memegang fungsi utama penegakan hukum. Selain itu kepolisian juga dituntut untuk melayani tujuan sosial berupa penjagaan keamanan dan ketertiban serta memberikan perlindungan, pengayoman dan pelayanan kepada masyaraka. ${ }^{1}$ Inilah yang seringkali menjadi dilema bagi aparat kepolisian karena tujuan sosial berupa penjagaan terhadap ketertiban seringkali bertolak belakangan tujuan hukum yang menghendaki kepastian

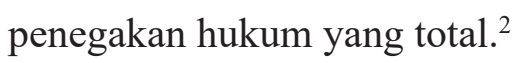

Salah satu tugas yang dibebankan kepada kepolisian adalah penanganan permasalahan lalu lintas baik yang bersifat prefentif maupun represif. Kepolisian dituntut untuk menjaga ketertiban lalu lintas selain juga harus menegakkan hukum pidana lalu lintas. Lahirnya Undang-undang Republik Indonesia Nomor 22 Tahun 2009 tentang Lalu Lintas dan Angkutan Jalan (selanjutnya disebut UULLAJ) sebagai ganti atas Undang-undang Nomor 14 tahun 1992 tentang Lalu Lintas dan Angkutan Jalan memberikan peneguhan kepada aparat kepolisian sebagai lembaga negara yang memiliki kewenangan paling luas dibanding lembaga lain dalam hal penegakan hukum pidana lalu lintas dan ketertiban di jalan raya. ${ }^{3}$

Lalu lintas didefinisikan sebagai gerak kendaraan dan orang di ruang lalu lintas jalan, sedangkan angkutan adalah perpindahan orang dan/atau barang dari satu tempat ke tempat lain dengan menggunakan kendaraan di ruang lalu lintas jalan. ${ }^{4}$ Segi positif dari lalu lintas dan angkutan adalah perannya yang strategis dalam mendukung pembangunan

1 Pasal 13 UU Kepolisian.

2 Satjipto Rahardjo, Penegakan Hukum Suatu tinjauan Sosiologis, Genta Publishing, Yogyakarta, 2011, hlm. 113.

3 Pasal 5 ayat 3 huruf e UU LLAJ menyatakan Pembinaan Lalu Lintas dan Angkutan Jalan sebagaimana dimaksud pada ayat (2) dilaksanakan oleh instansi pembina sesuai dengan tugas pokok dan fungsinya yang meliputi urusan pemerintahan di bidang Registrasi dan Identifikasi Kendaraan Bermotor dan Pengemudi, Penegakan Hukum, Operasional Manajemen dan Rekayasa Lalu Lintas, serta pendidikan berlalu lintas, oleh Kepolisian Negara Republik Indonesia.

4 Pasal 1UU LLAJ. 
Tabel 1

Data Kecelakaan dan Pelanggaran Lalu Lintas Tahun 2010 dan 2011 Kota Malang ${ }^{6}$

\begin{tabular}{|c|l|c|c|c|}
\hline No. & \multicolumn{1}{|c|}{ Jenis Kasus } & Tahun 2010 & Tahun 2011 & Trend \% \\
\hline 1. & Jumlah Kecelakaan & 183 & 317 & 73,22 \\
\hline 2. & Korban Meninggal Dunia & 74 & 97 & 31,08 \\
\hline 3. & Korban Luka Berat & 39 & 27 & $-30,76$ \\
\hline 4. & Korban Luka Ringan & 173 & 358 & 106,93 \\
\hline 5. & Rugi Materiil & 105.125 .000 & 188.325 .000 & 79,18 \\
\hline 6. & Jumlah Penyelesaian & 164 & 252 & 53,65 \\
\hline 7. & Jumlah Pelanggaran & 22561 & 35003 & 55,14 \\
\hline 8. & Jumlah Denda & 1.692 .075 .000 & 2.275 .195 .000 & 34,46 \\
\hline
\end{tabular}

dan integrasi nasional, namun dalam prosesnya, lalu lintas juga membawa segi yang negatif dimana tanpa diduga dan tidak disengaja terjadi kecelakaan yang melibatkan kendaraan dengan atau tanpa pengguna jalan lain yang mengakibatkan korban manusia atau kerugian harta benda. Inilah faktor yang perlu mendapatkan perhatian yang serius dari berbagai kalangan.

Secara faktuil angka kecelakaan lalu lintas di Indonesia mengalami kenaikan yang signifikan. Jawa Timur dengan jumlah penduduk terpadat di Indonesia misalnya, selama tahun 2011 angka kecelakaan lalu lintas tercatat naik 9.956 kasus atau 88,1\%, yakni dari 11.295 kasus pada tahun 2010 menjadi 21.251 kasus pada tahun 2011 dengan jumlah korban meninggal dunia dari 5.422 korban pada tahun 2010 menjadi 5.395 korban pada tahun 2011. ${ }^{5}$ Lebih khusus kota Malang sebagai kota terbesar kedua di Jawa Timur, angka kecelakaannya mengalami kenaikan yang signifikan sejumlah 73,22\% dari 183 kasus kecelakaan di tahun 2010 menjadi 317 kasus di tahun 2011, dengan perincian:

Tabel di atas menunjukkan kasus kecelakaan lalu lintas di Kota Malang merupakan salah satu penyumbang angka kematian dan korban luka terbesar dibanding tindakan kriminal lainnya. Faktor penyebab terjadinya kecelakaan lalu lintas sangat bervariasi, mulai dari kesalahan atau kelalaian pengemudi bahkan korban sampai pada keteledoran pemerintah setempat dalam mengatur kualitas dan kuantitas manajemen jalan raya di daerahnya. Hal ini tentunya harus direspons oleh petugas kepolisian dalam rangka menjaga ketertiban dan melakukan penegakan hukum pidana lalu lintas.

UU LLAJ yang baru telah diberlakukan sejak tahun 2010 diharapkan dapat menyelesaikan masalah turunan akibat adanya

5 Kecelakaan lalu lintas di Jatim naik 88, 1\% http://www.antaranews.com/berita/1325162344/kecelakaan-lalulintas-di-jatim-naik-88-1, diakses 17 April 2012 pukul 12.12 WIB.

6 Catatan Akhir Tahun Kriminalitas di Kota Malang. http://wartamalang.com/2011/12/catatan-akhir-tahunkriminalitas-di-kota-malang-2011/, diakses 15 April 2012 pukul 12.12 WIB. 
kecelakaan lalu lintas. Proses penegakan hukum yang seringkali berbelit-belit membuat sebagian besar masyarakat enggan menyelesaikan permasalahan mereka melalui aparat kepolisian.

Secara normatif tugas dan wewenang polisi berkait dengan proses peradilan lalu lintas meliputi pembinaan di bidang lalu lintas, penyidikan tindak pidana di bidang lalu lintas dan angkutan jalan. Kepolisian juga berwenang untuk melakukan pemeriksaan atas kebenaran keterangan berkenaan dengan pemenuhan persyaratan teknis dan layak jalan kendaraan bermotor. Dalam melaksanakan tugas penegakan hukum pidana lalu lintas ini, aparat Kepolisian tunduk pada aturan-aturan khusus untuk melakukan tindakan hukum. Ketentuan ini tertuang dalam Kitab Undangundang Hukum Acara Pidana, Undang-undang Nomor 2 tahun 2002 tentang Kepolisian Negara Republik Indonesia (selanjutnya disebut UU Kepolisian), UU LLAJ serta aturan moral yang menjadi pedoman yang harus ditaati. Oleh karenanya tidak mungkin kerja polisi menjadi kaku karena tuntutan untuk cepat tanggap terhadap fenomena sosial dibandingkan secara rigid bertindak sesuai ketentuan tertulis. UU Kepolisian kewenangan atau otoritas yang dimiliki polisi untuk melakukan tindakan yang menyimpang sesuai dengan situasi dan pertimbangan hati nuraninya.

Pasal 18 UU Kepolisian menyatakan:

1. Untuk kepentingan umum pejabat Kepolisian Negara Republik Indonesia dalam melaksanakan tugas dan wewenangnya dapat bertindak menurut penilaiannya sendiri.

2. Pelaksanaan ketentuan sebagaimana dimaksud dalam ayat (1) hanya dapat dilakukan dalam keadaan yang sangat perlu dengan memperhatikan peraturan perundang-undangan, serta kode etik profesi kepolisian negara republik Indonesia

Pasal tersebut memberikan kewenangan penuh kepada pejabat kepolisian untuk bertindak menurut penilaiannya sendiri, dalam kata lain aparat kepolisian memiliki kewenangan untuk melakukan diskresi. Dengan kewenangan diskresi yang dimiliki tersebut, maka bisa jadi ada satu persoalan hukum yang tidak diselesaikan melalui jalur pengadilan melainkan diserahkan penyelesaiannya pada keputusan anggota polisi. Apalagi secara faktual tidak setiap kasus kecelakaan lalu lintas selalu berakhir di pengadilan. Kasus kecelakaan lalu lintas lebih sering berakhir dengan perjanjian damai di antara kedua belah pihak atau lebih, hal ini dimungkinkan karena UU LLAJ memberikan peluang kepada aparat kepolisian untuk memfasilitasi upaya perdamaian di luar pengadilan. Hal ini dapat kita lihat dalam Pasal 236 ayat (2) UU LLAJ:

Kewajiban mengganti kerugian sebagaimana dimaksud pada ayat pada Kecelakaan Lalu Lintas sebagaimana dimaksud dalam Pasal 229 ayat (2) dapat dilakukan di luar pengadilan jika terjadi 
kesepakatan damai diantara para pihak yang terlibat.

Penggunaan diskresi Kepolisian menjadi isu yang menarik untuk diteliti karena korelasinya dengan proses penyelesaian kasus kecelakaan lalu lintas, tentunya penggunaan diskresi ini tidak dimaksudkan sebagai solusi satu-satunya untuk menanggulangi kecelakaan lalu lintas namun sebagai salah satu pintu keluar dalam menyelesaikan problematika yang timbul sebagai efek adanya kecelakaan lalu lintas. Oleh karenanya ada 2 (dua) permasalahan yang menjadi fokus perhatian penulis berkaitan dengan latar belakang yang telah dikemukakan, yaitu pertama, Faktor apa saja yang melatarbelakangi Kepolisian Resort Malang Kota menerapkan diskresi dalam menyelesaikan perkara kecelakaan lalu lintas? Kedua Bagaimana mekanisme penggunaan diskresi yang diterapkan Kepolisian Resort Malang Kota dalam penyelesaian perkara kecelakaan lalu lintas?

\section{Pembahasan}

\section{A. Prosedur Pertama Dalam} Penanganan Perkara Kecelakaan Lalu Lintas

Sebagai optimalisasi Program Quick Wins 2010 bidang peningkatan pelayanan penanganan kecelakaan lalu lintas, Petugas Unit Kecelakaan dan Lalu Lintas Satuan Polisi Lalu Lintas Polres (laka lantas) Malang Kota mempersiapkan dan memperhatikan hal-hal sebagai berikut: ${ }^{7}$

1. Menerima laporan dan pengaduan laka lantas.

a. Tempat dilaksanakan di Kantor Polres Malang Kota.

b. Di pos-pos tetap di Wilayah Polres Malang Kota.

c. Menerima laporan yang disampaikan seseorang secara tertulis maupun lisan tentang suatu peristiwa kecelakaan lalu lintas.

d. Menerima dan mencatat identitas pelapor dimana lokasi terjadinya kecelakaan lalu lintas.

2. Dalam hal penanganan laka lantas, terutama perihal kecepatan anggota laka lantas Polres Malang Kota dalam pelaksanaannya mendatangi TPTKP lantas dengan tenggang waktu dari menerima laporan sampai dengan tiba di lokasi laka lantas maksimal 15 menit.

3. Unit laka lantas Polres Malang Kota didukung dengan pos tetap yang ada di setiap wilayah polsek masing-masing, dan ditambah pos TAC (Traffic Accident Center) serta pos pantau yang ada di jalur rawan laka / black spot memiliki berbagai fasilitas pendukung yaitu:

a. Kendaraan unit laka untuk ke TPTKP.

b. Kendaraan ambulance yang dilengkapi dengan Traffic Accident $B o x$ yang digunakan untuk

7 Humas Polres Kota Malang, Standar Operasional Prosedur (SOP) Pam Dan Olah TKP Laka Lantas Traffic Accident Center Sat Lantas Polres Malang Kota, Malang, 2010, hlm. 1. 
mendatangi TKP dengan kecepatan dan mobilitas yang tinggi diharapkan mampu untuk memberikan pertolongan serta penanganan laka lantas secara maksimal.

Setibanya di tempat kejadian perkara kecelakaan lalu lintas, tindakan yang harus dilakukan oleh anggota Sat Lantas Kepolisian Resort Malang Kota antara lain: ${ }^{8}$

1. Mengamankan TKP kecelakaan lalu lintas agar tidak terjadi kecelakaan lalu lintas baru.

2 Memberikan pertolongan pertama kepada korban.

3. Mengamankan tersangka dan saksi serta mengumpulkannya pada tempat di luar batas yang telah ditentukan.

4. Mengamankan barang bukti kecelakaan lalu lintas.

5. Memisahkan saksi dan tersangka dengan maksud untuk tidak saling mempengaruhi.

6. Membuat tanda di TKP kecelakaan lalu lintas.

1) Terhadap kendaraan yang terlibat kecelakaan lalu lintas.

2) Terhadap korban kecelakaan lalu lintas.

3) Terhadap alat bukti lainnya.

4) Terhadap titik tabrak.

5) Terhadap bekas rem.
6) Setelah alat bukti diberi tanda dan di foto segera dipindahkan ke tepi jalan sehingga arus lalu lintas dapat lancar kembali.

7. Untuk penanganan di jalur Black Spot yang dilakukan oleh Tim Laka Lantas Terpadu, setiba di TKP, masing-masing instansi melakukan sesuai tugas dan tanggung jawabnya.

Selanjutnya, petugas Polresta Malang dalam rangka penyelidikan maupun penyidikan tindak pidana kecelakaan lalu lintas melakukan pengamatan secara umum, yang meliputi pengamatan terhadap keadaan jalan (sempit/lebar/tanjakan/turunan/ tikungan/simpangan/lurus dan lain-lain), keadaan lingkungan (ramai/sepi/bebas pandangan dan lain-lain), keadaan cuaca pada waktu terjadi kecelakaan lalu lintas, kendaraan yang terlibat kecelakaan lalu lintas, kerusakan pada kendaraan, kerusakan pada jalan dan kelengkapannya, letak kendaraan dan korban, bekas-bekas tabrakan yang tertinggal di jalan seperti; bekas rem, pecahan kaca, tetesan darah, bekas cat/dempul, bekas oli, suku cadang yang terlepas/jatuh dan lain-lain dan arah datangnya kendaraan yang terlibat kecelakaan. ${ }^{9}$

Selain itu, petugas Polresta Malang juga melakukan pemeriksaan terhadap kendaraan yang terlibat kecelakaan lalu lintas, berupa kelengkapan surat-surat kendaraan

8 Ibid., hlm. 2.

9 Interview dengan BRIPTU Robby Arya W, penyidik Unit Laka Lantas Polresta Malang tanggal 12 September 2012. 
(STNK,STCK, Buku Kir), keadaan lampulampu kendaraan (apakah semua menyala dengan baik dan bagaimana penyetelan tinggi rendahnya sorot lampu), keadaan klakson, keadaan alat penghapus kaca, kedudukan porseneling pada gigi berapa. keadaan kemudi, penyetelan dari pada kaca spion, kondisi rem, kondisi ban kendaraan, kedudukan spido meter/ ukuran kecepatan kendaraan, kondisi per dan muatan kendaraan.

Kondisi jalan dan kelengkapannya seperti kondisi jalan (hotmix/ sirtu/ berlobang/ bergelombang dan lain-lain), rambu-rambu yang ada di sekitar TKP. Kondisi bahu jalan dan Marka jalan tempat terjadinya kecelakaan juga dilakukan pemeriksaan demi mengetahui lebih jelas faktor dominan penyebab kecelakaan lalu lintas.

Mengenai pemeriksaan yang dilakukan terhadap tersangka, Aparat Kepolisian wajib mengamankan tersangka termasuk memberikan perlindungan apabila ada masyarakat yang main hakim sendiri, selanjutnya melakukan interview dengan mengajukan pertanyaan singkat kepada tersangka untuk memperoleh keterangan sementara tentang bagaimana terjadinya peristiwa kecelakaan tersebut di samping mencatat indentitas tersangka (SIM, KTP dan lain-lain). ${ }^{10}$

Untuk kepentingan pembuktian, diperlukan adanya pemotretan di TKP, yang terdiri dari foto situasi TKP secara keseluruhan, sebanyak 4 (empat) kali dari 4 (empat) penjuru, foto posisi dari kendaraan yang terlibat kecelakaan, sebanyak 4 (empat) kali dari 4 (empat) penjuru, foto korban sebelum dipindahkan dari TKP, foto kerusakan yang ada pada kendaraan yang terlibat kecelakaan lalu lintas dan foto bekas-bekas yang tertinggal di TKP seperti bekas rem, pecahan kaca, pecahan cat/dempul dan hal lain. Setelah pengolahan TKP kecelakaan lalu lintas selesai dilaksanakan maka dilakukan pengecekan terhadap personil, perlengkapan dan segala hal yang diketahui, ditemukan dan yang dilakukan di TKP. Kemudian TKP dibuka dengan konsekuensi arus lalu lintas harus normal kembali. Langkah penting lanjutan adalah petugas melakukan permintaan Visum et Repertum ke Rumah Sakit di mana korban dirawat.

Pembuatan Berita Acara Pemeriksaan di TKP dibuat oleh Penyidik/ Penyidik Pembantu yang melakukan pengolahan TKP, dengan materi hasil yang diketemukan di TKP baik TKP itu sendiri, korban, saksisaksi, tersangka maupun barang bukti, dant tindakan yang dilakukan oleh petugas (TPTKP dan pengolahan TKP) tehadap hasil yang ditemukan di TKP. Di samping Berita Acara Pemeriksaan di TKP dibuat juga Berita Acara lain-lain sesuai tindakan yang dilakukan. ${ }^{11}$

10 Ibid.

11 Interview dengan AIPTU Safari, SH, penyidik Unit Laka Lantas Polresta Malang tanggal 12 September 2012. 


\section{b. Proses Penyelesaian Perkara} Tindak Pidana Kecelakaan Lalu Lintas Di Kepolisian Resort Malang Kota

Proses penyelesaian perkara tindak pidana kecelakaan lalu lintas tunduk pada aturan KUHAP, dimana selaku penyidik, petugas Kepolisian Resort Malang Kota memiliki wewenang sebagaimana diatur di dalam pasal 7 (1) KUHAP yaitu:

a) Menerima laporan atau pengaduan dari seorang tentang adanya tindak pidana;

b) Melakukan tindakan pertama pada saat di tempat kejadian;

c) Menyuruh berhenti seorang tersangka dan memeriksa tanda pengenal diri tersangka;

d) Melakukan penangkapan, penahanan, penggeledahan dan penyitaan;

e) Melakukan pemeriksaan dan penyitaan surat;

f) Mengambil sidik jari dan memotret seorang;

g) Memanggil orang untuk didengar dan diperiksa sebagai tersangka atau saksi;

h) Mendatangkan orang ahli yang diperlukan dalam hubungannya dengan pemeriksaan perkara;

i) Mengadakan penghentian penyidikan;

j) Mengadakan tindakan lain menurut hukum yang bertanggung jawab.
Penyidik Kepolisian Resort Kota Malang dalam kurun waktu tahun 2011 hingga bulan Agustus tahun 2012 telah menangani 537 kejadian kecelakaan lalu lintas. Dari total 537 kejadian kecelakaan lalu lintas terdapat 153 korban meninggal dunia, 35 korban luka berat dan 601 korban luka ringan dengan total kerugian Rp. 442.500.000,- (empat ratus empat puluh dua juta lima ratus ribu rupiah).

Proses penyelesaian perkara kecelakaan lalu lintas oleh penyidik Kepolisian Resort Kota Malang pada kurun waktu 2011-2012, jika dicermati dari total 537 kasus di atas hanya 15 kasus yang disidik dan diteruskan ke penuntutan hingga dilimpahkan ke pengadilan. Sebanyak 59 kasus lainnya dihentikan dengan dasar SP3. Dasar penghentian 59 kasus tindak pidana kecelakaan lalu lintas adalah Pasal 140 ayat 2 huruf a KUHAP dikarenakan tersangka meninggal dunia, nebis in idem atau daluwarsa dan Pasal 76, 77, 78 KUHP. ${ }^{12}$

Penyelesaian melalui jalur perdamaian I Alternative Dispute Resolutions cukup mendominasi angka penyelesaian perkara kecelakaan lalu lintas, sebanyak 355 kasus atau hampir 70\% kasus diselesaikan dengan cara ini. Hal ini menurut Kanit Laka Lantas Polres Malang Kota merupakan salah satu dari implementasi diskresi dalam penyelesaian perkara tindak pidana kecelakaan lalu lintas. ${ }^{13}$

12 Interview dengan IPDA Hudi Susilo SH, Kepala Unit Kecelakaan Lalu Lintas Polresta Malang tanggal 19 September 2012.

13 Ibid. 


\section{Faktor Yang Melatarbelakangi Kepolisian Resort Malang Kota Menerapkan Diskresi Dalam Menyelesaikan Perkara Kecelakaan Lalu Lintas}

Bentuk diskresi Kepolisian Resort Malang Kota dalam kasus kecelakaan lalu lintas adalah melalui jalur mediasi penal dengan cara mengupayakan penyelesaian di antara pihak yang terlibat dengan jalan damai melalui mekanisme Alternative Dispute Resolutions / ADR. Penyidik memberikan peluang terhadap pihak-pihak yang berperkara untuk melakukan kesepakatan perdamaian. ${ }^{14}$

Terdapat dua faktor yang melatarbelakangi Kepolisian Resort Malang Kota menerapkan diskresi dalam hampir semua penyelesaian perkara kecelakaan lalu lintas melalui jalur mediasi penal. Faktor pertama menurut Kanit Laka Lantas Polres Malang Kota adalah secara internal adanya Surat Kapolri Nopol B/3022/ $\mathrm{XII} / 2009 /$ Sdeops tanggal 14 Desember 2009 tentang penanganan kasus melalui Alternative Dispute Resolution (ADR) yang dipertegas dengan Surat Telegram Kapolda Jatim Nomor ST/476/II/2010/Ditlantas yang memerintahkan agar para penyidik di wilayah Jawa Timur yang menangani kasus kecelakaan lalu lintas yang mengakibatkan luka ringan / kerugian materiil dapat diselesaikan melalui konsep Alternative Dispute Resolution. ${ }^{15}$ Kepolisian Negara Republik Indonesia
Daerah Jawa Timur Direktorat Lalu Lintas melalui surat pada bulan Juni 2010 memberikan pedoman tentang ADR dalam kasus kecelakaan lalu lintas dimana klasifikasi kasus yang dapat di ADR antara lain juga termasuk kasus yang sudah dinyatakan berkasnya lengkap oleh Penuntut Umum atau P.21 dengan korban meninggal dunia dan luka berat. Hal ini menurut surat tersebut dilakukan demi kepentingan umum, dimana pejabat Kepolisian Negara Republik Indonesia dalam melaksanakan tugasnya dan kewenangannya dapat bertindak menurut penilaian sendiri dan hanya dilakukan dalam keadaan yang sangat perlu dengan memperhatikan perundangundangan dan kode etik Profesi Polri. ${ }^{16}$

Dasar-dasar inilah yang digunakan oleh aparat Kepolisian Resort Malang Kota dalam menyelesaikan 355 kasus atau hampir 70\% perkara kecelakaan lalu lintas selama kurun waktu 2011-2012 melalui jalur perdamaian I Alternative Dispute Resolutions dengan klasifikasi tindak pidana kecelakaan lalu lintas dengan kerugian materiil, korban luka ringan, luka berat bahkan meninggal dunia.

Selain itu faktor kedua yang melatarbelakangi Kepolisian Resort Malang Kota menerapkan menggunakan diskresi adalah adanya Pasal 16 ayat (2) UU Kepolisian dimana disebutkan aparat kepolisian dapat melakukan tindakan lain menurut hukum yang bertanggung jawab. Maksudnya tindakan- 
tindakan penyidikannya yang dilaksanakan harus memenuhi syarat antara lain tidak bertentangan dengan aturan hukum, selaras dengan kewajiban hukum yang mengharuskan tindakan tersebut dilakukan, harus patut masuk akal dan termasuk dalam lingkungan jabatannya, Pertimbangan layak berdasarkan keadaan yang memaksa dan menghormati HAM. $^{17}$

Menurut analisa penulis, faktor pertama yang melatarbelakangi penggunaan diskresi dalam bentuk mediasi penal secara normatif dapat kita lacak pada pasal 236 (2) UULLAJ dimana dalam kasus tertentu kecelakaan lalu lintas dapat diselesaikan di luar persidangan. Jika terjadi kesepakatan damai di antara pihak yang terlibat kerugiannya material dan ganti rugi dapat dilakukan di luar PN. Jika terdapat korban luka ringan digunakan Berita Acara Cepat dan bila ada kerugian materiil yang sangat ringan sifatnya dapat digunakan mekanisme denda/ tilang. Indikator yang digunakan untuk menjabarkan Pasal 236 ayat (2) UULLAJ adalah luka ringan yang diderita korban dalam waktu dekat cepat sembuh dan tidak menyebabkan cidera tetap, kasus tersebut tidak menimbulkan keresahan di masyarakat, kecelakaan yang tidak melibatkan korban masal serta kerugian materiil yang ditimbulkan sangat kecil. ${ }^{18} \mathrm{Ke}$ semua indikator tersebut menjadi dasar bagi para penyidik di lapangan ketika menggunakan kewenangan diskresinya dalam melakukan penyelesaian kasus kecelakaan lalu lintas ringan.

Lebih lanjut, penerapan diskresi dalam Pasal 18 UU Kepolisian ternyata tidak hanya digunakan untuk kasus kecelakaan lalu lintas ringan saja sebagaimana diatur dalam Pasal 236 ayat (2) UULLAJ. Faktor yang melatarbelakangi digunakannya ADR untuk tindak pidana kecelakaan lalu lintas dengan kerugian materiil, korban luka ringan, luka berat bahkan meninggal dunia diakui oleh Kanit Laka Lantas Polresta Malang selain perintah dari Mabes Polri dan Polda Jatim adalah karena murni alasan kemanusiaan dan budaya masyarakat Malang yang tidak menginginkan proses yang berbelit-belit dan cenderung memilih jalan damai. Oleh karenanya jika ada kesepakatan damai diantara pihak-pihak yang terlibat dalam kecelakaan lalu lintas tersebut, maka penyidik Kepolisian Resort Malang kota tidak akan memproses dan melanjutkannya ke tahap penuntutan dan peradilan. ${ }^{19}$

Menurut pendapat penulis, secara normatif penggunaan diskresi yang dilakukan oleh Kepolisian Resort Malang Kota khusus untuk proses penyelesaian perkara tindak pidana kecelakaan lalu lintas dengan kerugian materiil dimana termasuk kategori tindak pidana kecelakaan lalu lintas ringan sesuai dengan ketentuan Pasal 236 ayat (2) UULLAJ. Namun proses penyelesaian

17 Ibid.

18 Ibid.

19 Interview dengan IPDA Hudi Susilo SH, Kepala Unit Kecelakaan Lalu Lintas Polresta Malang tanggal 19 September 2012. 
dengan menggunakan perdamaian yang diterapkan dengan alasan diskresi pada kasus tindak pidana kecelakaan lalu lintas sedang dengan korban luka ringan dan tindak pidana kecelakaan lalu lintas berat dengan korban luka berat dan meninggal dunia tidak sesuai dengan ketentuan Pasal 310 UU LLAJ dimana delik kecelakaan lalu lintas merupakan delik biasa bukan delik aduan. Dan tidak ada satu aturanpun dalam UU LLAJ yang memberikan peluang kepada aparat penegak hukum untuk mengupayakan perdamaian. Bahwa kemudian hal ini disebut diskresi demi kepentingan umum dengan mengacu pada Pasal 16 dan 18 UU Kepolisian dan surat Kapolri Nopol B/3022/XII/2009/Sdeops tanggal 14 Desember 2009 tentang penanganan kasus melalui Alternative Dispute Resolution (ADR) dan Surat Telegram Kapolda Jatim Nomor ST/476/II/2010/Ditlantas dari prespektif kemanfaatan dan keadilan mungkin bisa dibenarkan, namun hal ini tidak menjamin kepastian hukum. Karena secara yuridis kedua surat tersebut bisa dikatakan batal demi hukum karena bertentangan dengan peraturan yang lebih tinggi dalam hal ini UU LLAJ.

\section{Mekanisme Penggunaan Diskresi Dalam Penyelesaian Perkara Kecelakaan Lalu Lintas Di Kepolisian Resort Malang Kota}

Mekanisme Mediasi penal sebagai bentuk diskresi dalam penyelesaian perkara kecelakaan lalu lintas adalah sebagai berikut:
- Kesepakatan tertulis dari masing-masing pihak yang terlibat dalam kecelakaan lalu lintas (pelaku, korban) yang ditandatangani di atas segel dan diberi materai, diketahui/disetujui oleh ketua RT/RW atau kepala lingkungan dan diketahui oleh para saksi-saksi lainnya. Penyelesaian menggunakan ADR harus berprinsip pada musyawarah mufakat dan harus diketahui oleh masyarakat sekitar serta harus menghormati norma sosial/adat yang berlaku serta memenuhi asas keadilan.

- Setelah terjadi kesepakatan perdamaian, penyidik mencatat kecelakaan lalu lintas tersebut dalam buku register dan didatakan dengan baik.

Berdasarkan Surat Kapolri Nopol B/3022/ XII/2009/Sdeops tanggal 14 Desember 2009 tentang penanganan kasus melalui Alternative Dispute Resolution (ADR) dinyatakan untuk kasus yang telah diselesaikan dengan ADR agar tidak lagi disentuh oleh tindakan hukum lain yang kontra produktif dengan tujuan polmas. ${ }^{20}$

- Apabila tidak terdapat kesepakatan di antara para pihak baru diselesaikan sesuai prosedur hukum yang berlaku secara profesional dan proporsional.

Sebagai contoh mekanisme kasus kecelakaan lalu lintas yang diproses dengan cara diskresi sebagaimana dimaksud dalam Pasal 18 UU Kepolisian adalah kecelakaan 
lalu lintas dimana antara korban dan tersangka masih ada hubungan keluarga. A (bapak) membonceng $\mathrm{B}$ (istri) dan C (anaknya) terlibat kecelakaan lalu lintas mengakibatkan istri atau anaknya meninggal dunia sedang yang menjadi tersangka adalah A (bapaknya). Langkah yang dilakukan dalam penggunaan diskresi oleh penyidik Kepolisian Resort Malang Kota adalah sebagai berikut:

1. Tetap dilakukan penyidikan sampai menjadi BAP lengkap

2. Bila perlu tersangka tidak ditahan

3. SPDP belum perlu dikirim ke PU

4. Tersangka tidak dibebani apapun

5. Dilakukan gelar perkara yang dipimpin waka dan dihadiri Kasat Lantas, Kasat Serse, Kasat Intel, Provos, Kanit Laka, penyidik Laka dan hasilnya dilaporkan ke Kapolresta sebagai bahan untuk mengambil keputusan namun penyidik tetap harus memantau perkembangannya dengan mendengarkan saran dari masyarakat.

Setelah dilakukan gelar perkara dan mendengarkan saran dari masyarakat, Kapolresta akan memutuskan apakah kasus A (bapak) sebagai tersangka atas kecelakaan lalu lintas tersebut diteruskan atau ditangguhkan. ${ }^{21}$

Contoh kasus lain terkait kecelakaan lalu lintas yang mengakibatkan korban meninggal dunia, luka berat namun kedua belah pihak telah sepakat damai dengan membuat surat pernyataan yang diketahui oleh RT/RW/
Kepala Desa/Kepala Kelurahan setempat, maka langkah yang dilakukan penyidik adalah:

1. Menyelesaikan BAP secara lengkap

2. SPDP belum perlu dikirim ke PU

3. Dilakukan gelar perkara yang dipimpin Wakapolresta dan dihadiri Kasat Lantas, Kasat Serse, Kasat Intel, Provos, Kanit Laka, penyidik Laka dan hasilnya dilaporkan ke Kapolres sebagai bahan untuk mengambil keputusan namun penyidik tetap harus memantau perkembangannya dengan mendengarkan saran dari masyarakat

4. Pelaporan penyelesaian perkara ke Polda dapat dikategorikan penangguhan jika ada persetujuan dari Kapolres. ${ }^{22}$

Kendala yang dihadapi dalam penggunaan diskresidalamkeduacontohkasusdiatasadalah diperlukan adanya pengawas penyidik yang memantau dan memonitoring perkembangan penyidikan agar tidak disalahgunakan dengan melakukan pengawasan internal penyidikan yang dilakukan secara berjenjang dan melekat kepada setiap penyidik. Hal ini sulit dilakukan karena keterbatasan sumber daya materi dan manusia. Kendala lain yaitu mekanisme gelar perkara yang selalu dipimpin oleh wakapolres maupun kasat lantas membuat tidak semua perkara bisa dilakukan gelar dalam waktu yang cepat. Sehingga diperlukan pembinaan mental kepada anggota kepolisian secara terus menerus guna merubah mindset dalam 
menangani kasus kecelakaan lalu lintas. ${ }^{23}$

Menurut penulis, untuk kategori tindak pidanakecelakaanlalulintasringan,mekanisme yang dilakukan oleh kepolisian sudah tepat, karena sudah sesuai dengan ketentuan Pasal 236 ayat (2) UULLAJ yang memberikan peluang proses penyelesaian perkara di luar peradilan, meski mekanismenya tidak diatur dalam UULLAJ namun Surat Kapolri Nopol B/3022/XII/2009/Sdeops tanggal 14 Desember 2009 tentang penanganan kasus melalui Alternative Dispute Resolution (ADR) dapat dijadikan acuan dalam menyelesaikan tindak pidana kecelakaan lalu lintas ringan.

Namun jika ditelaah lebih lanjut, untuk tindak pidana kecelakaan sedang dan tindak pidana kecelakaan berat dengan korban luka berat dan meninggal dunia, mekanisme penggunaan diskresinya tidak sesuai dengan KUHAP dan bahkan UULLAJ. KUHAP hanya mengenal penghentian penyidikan itupun dengan syarat yang sangat limitatif sedangkan UULLAJ tidak memberikan peluang penggunaan ADR dalam tindak pidana kecelakaan sedang dan tindak pidana kecelakaan berat dengan korban luka berat dan meninggal dunia. Hal it tentu berbeda dengan praktik yang dilakukan oleh Kepolisian Resort Malang Kota dengan dasar Surat Kapolri Nopol B/3022/XII/2009/ Sdeops tanggal 14 Desember 2009 tentang penanganan kasus melalui Alternative Dispute Resolution (ADR), dari dua contoh kasus di atas dapat dilihat tidak adanya kepastian mengenai status tersangka. Apakah dihentikan? Ataukah dilanjutkan? Yang ada hanyalah status bagi tersangka berdasarkan keputusan Kapolres adalah ditangguhkan. Meski dalam Surat Kapolri Nopol B/3022/ XII/2009/Sdeops tanggal 14 Desember 2009 tentang penanganan kasus melalui Alternative Dispute Resolution (ADR) untuk kasus yang sudah mendapatkan keputusan dari Kapolres tidak boleh disentuh oleh tindakan hukum lagi, namun hal ini sangat rawan disalahgunakan oleh oknum aparat penegak hukum. Harusnya diatur yang jelas dan tegas dalam peraturan perundang-undangan mengenai mekanisme diversi untuk kasus kecelakaan lalu lintas, untuk menjamin kepastian hukum

\section{Simpulan}

Faktor yang melatarbelakangi digunakannya diskresi dalam bentuk penyelesaian perkara melalui jalur perdamaian dalam menyelesaikan 355 kasus atau hampir $70 \%$ perkara kecelakaan lalu lintas selama kurun waktu 2011-2012 dengan klasifikasi tindak pidana kecelakaan lalu lintas dengan kerugian materiil, korban luka ringan, luka berat bahkan meninggal dunia adalah secara internal Kepolisian terdapat Surat Kapolri Nopol B/3022/XII/2009/Sdeops tanggal 14 Desember 2009 tentang penanganan kasus melalui Alternative Dispute Resolution (ADR) yang dipertegas dengan Surat Telegram Kapolda Jatim Nomor ST/476/ II/2010/Ditlantas yang memerintahkan 
untuk memberikan peluang bagi para pihak yang terlibat untuk melakukan perdamaian, dan dari sisi faktor eksternal adalah alasan kemanusiaan dan budaya masyarakat yang tidak menginginkan proses yang berbelit-belit dan cenderung memilih jalan damai. Oleh karenanya jika ada kesepakatan damai diantara pihak-pihak yang terlibat dalam kecelakaan lalu lintas tersebut, maka penyidik Kepolisian Resort Malang Kota tidak akan memproses dan melanjutkannya ke tahap penuntutan dan peradilan

Mekanisme Alternative Dispute Resolution (ADR) sebagai bentuk diskresi penanganan kasus kecelakaan lalu lintas adalah penyidik memberikan peluang terhadap pihak-pihak yang berperkara untuk melakukan kesepakatan perdamaian /ADR. Tahapan mekanisme yang dilakukan antara lain adanya kesepakatan tertulis dari masing-masing pihak yang terlibat dalam kecelakaan lalu lintas (pelaku, korban) yang ditandatangani di atas segel dan diberi materai, diketahui/disetujui oleh ketua

\section{Buku}

Satjipto Rahardjo, 2011, Penegakan Hukum

Suatu tinjauan Sosiologis, Genta

Publishing, Yogyakarta.

Humas Polres Kota Malang, 2010, Standar

Operasional Prosedur (SOP) Pam

Dan Olah TKP Laka Lantas Traffic

Accident Center Sat Lantas Polres
RT/RW atau kepala lingkungan dan diketahui oleh para saksi-saksi lainnya. Setelah terjadi kesepakatan perdamaian, penyidik mencatat kecelakaan lalu lintas tersebut dalam buku register dan didatakan dengan baik. Sedangkan mekanisme diskresi dalam pengambilan keputusan untuk kasus kecelakaan lalu lintas yang mengakibatkan korban meninggal dunia, luka berat jika kedua belah pihak telah sepakat damai dengan membuat surat pernyataan yang diketahui oleh RT/RW/Kepala Desa/Kepala Kelurahan setempat, maka penyidik tetap menyelesaikan BAP secara lengkap, SPDP belum dikirim ke PU dan kemudian dilakukan gelar perkara yang dipimpin Wakapolresta dan dihadiri Kasat Lantas, Kasat Serse, Kasat Intel, Provos, Kanit Laka, penyidik Laka dan hasilnya dilaporkan ke Kapolres sebagai bahan untuk mengambil keputusan namun penyidik tetap harus memantau perkembangannya dengan mendengarkan saran dari masyarakat.

\section{DAFTAR PUSTAKA}

\section{Peraturan Perundang-undangan}

Kitab Undang-undang Hukum Pidana.

Kitab Undang-undang Hukum Acara Pidana.

Undang-undang Nomor 2 Tahun 2002 tentang Kepolisian Negara Republik 
Indonesia.

Undang-undang Nomor 20 Tahun 2009

tentang Lalu Lintas dan Angkutan Jalan.

\section{Artikel Internet}

Kecelakaan lalu lintas di Jatim naik

88,1\%, http://www.antaranews.com/ berita/1325162344/kecelakaan-lalulintas-di-jatim-naik-88-1.

Catatan Akhir Tahun Kriminalitas di Kota Malang, http://wartamalang. com/2011/12/catatan-akhir-tahunkriminalitas-di-kota-malang-2011/. 